\title{
OBTENTION OF WCUNI COMPOSITE MATERIAL USING POWDER METALLURGY FOR GAMMA (Y) RADIATION ATTENUATION.
}

\author{
Cione, F. C. ${ }^{1}$; Souza, A. C. ${ }^{2}$;Sene, F. F. ${ }^{1}$; Gomes, M. P. ${ }^{1 *}$; Soares, E. P. ${ }^{1}$; Rossi, J. L. ${ }^{1}$ \\ ${ }^{1}$ Instituto de Pesquisas Energéticas e Nucleares, IPEN - CNEN, São Paulo, SP, Brazil. \\ ${ }^{2}$ State University of Mato Grosso do Sul/ Department of Physics - CEPEMAT/UEMS, Dourados, MS, Brazil.
}

*e-mail: fceoni@.ipen.br

\begin{abstract}
This work aimed to obtain a composite material WCuNi using the powder metallurgy. This composite is usable as material for the attenuation of gamma radiation $(\mathrm{Y})$. The tungsten $(\mathrm{W})$ is the main shielding element in this composite. The tungsten has high density $\left(19.25 \mathrm{~g} . \mathrm{cm}^{-3}\right)$, high melting point $\left(3,422{ }^{\circ} \mathrm{C}\right)$ and is presented as matrix of the composite. In order to meet the need for sintering with temperatures below $1,200^{\circ} \mathrm{C}$, the liquid phase sintering technique was used. For preparation of the samples, shape and size of the particles of the metal powders were analyzed. With the intention of homogenize the distribution of the metallic powders and to reduce the average particle size, a ball mill was used for 24 hours. After grinding, the particle size analysis showed that the mean particle size in WCuNi composition was $12 \mu \mathrm{m}$. The powder mixture was compacted in isostatic press at $200 \mathrm{MPa}$ pressure. The samples were sintered at $1,100{ }^{\circ} \mathrm{C}$ and at 2,100 mbar pressure of reducing atmosphere $\left(\mathrm{H}_{2}\right)$ for 8 hours. The formation of the isomorphic system CuNi is responsible for giving the mechanical characteristic of solid to the composite WCuNi. Optical and electronic microscopy (SEM) with EDS were undertaken to characterize the samples. The classical scientific method of experimentations with gamma radiation of the cobalt-60 source by attenuation of the energies was employed to study the effects on the samples. For the energies of $1,173 \mathrm{MeV}$ and $1,332 \mathrm{MeV}$ the experimental method indicated the necessity of $11.95 \mathrm{~mm}$ of thickness for the solid compound W8Cu1Ni with the obtained density of $11.46 \mathrm{~g} \mathrm{~cm}^{-3}$ to attenuate the energy to level allowed for occupationally exposed persons. The experimental values obtained were compared with values calculated by XCOM software database (NIST) of $12.45 \mathrm{~mm}$ and convergence of values was observed.

Keywords: gamma ray attenuation, powder metallurgy, characterization.
\end{abstract}

\section{Resumo}

Este trabalho teve como objetivo obter um material metálico (WCuNi) por metalurgia do pó, para determinação do coeficiente de atenuação da radiação gama $(\mathrm{Y})$. O tungstênio (W) é o principal elemento de proteção neste composto, com alta densidade $\left(19,25\right.$ g.cm-3), alto ponto de fusão $\left(3.422^{\circ}\right.$ C) e está presente como matriz do composto. Para atender a necessidade de sinterização com temperaturas inferiores a $1.200^{\circ} \mathrm{C}$, foi utilizada a técnica de sinterização em fase líquida. Para a preparação das amostras de compostos, a forma e o tamanho das partículas dos pós metálicos foram verificados. Para homogeneizar a distribuição dos pós metálicos e reduzir o tamanho médio de partícula, utilizouse um moinho de bolas durante 24 horas. Após a moagem, a análise do tamanho de partícula mostrou que o tamanho médio de partícula na composição de WCuNi era de $12 \mu \mathrm{m}$. Para obter o verde compactado foi aplicado $200 \mathrm{MPa}$ sob pressão isostática. As amostras foram sinterizadas a $1.100^{\circ} \mathrm{C}$ e $2.100 \mathrm{mbar}$ de pressão na atmosfera de redução (H2) durante 8 horas. A formação do sistema isomórfico CuNi é responsável por dar características mecânicas sólidas ao composto WCuNi. Foram feitas microscopia óptica e eletrônica (SEM) com EDS para caracterizar o composto. O método científico clássico de experimentação com radiação gama da fonte de cobalto-60 por atenuação das energias foi empregado para estudar os efeitos e correções nas dimensões de blindagem necessárias. Para as energias de 1,173 $\mathrm{MeV}$ e 1,332 MeV, o método experimental indicou a necessidade de 11,95 mm de espessura para o composto sólido W8Cu1Ni com a densidade obtida de $11,46 \mathrm{~g} . \mathrm{cm}^{-3}$ para atenuar a energia aos níveis permitidos por normas para o grupo de pessoal ocupacional. Os valores experimentais obtidos foram comparados com os valores calculados com uso do banco de dados de software XCOM (NIST) de 12,45 mm e os valores de convergência foram observados.

Palavras-chave: atenuação da radiação gama, metalurgia do pó, caracterização.

\section{Introduction}

The relevance of nuclear science is noticed by the production of radio-pharmaceutical and radioactive substances used in therapy and diagnostic imaging for nuclear medicine. Safe transportation of radiopharmaceutical medicine is mandatory and dependent on radiation shielding material used [1]. Many researchers have been working to develop more usefully (environmental friendly, non-toxical, stationary and mobile) shielding material. Radio-pharmaceutical 


\section{Encontro Científico de Física Aplicada}

transportation equipments as Ganuk by Nordian and Generator IPEN-TEC (Fig. 1.1) generally use lead or uranium depleteas radiation shield $[2,3]$.

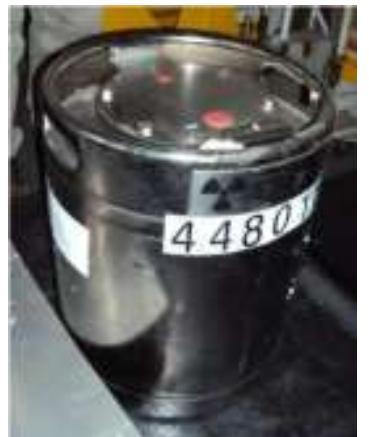

(a)

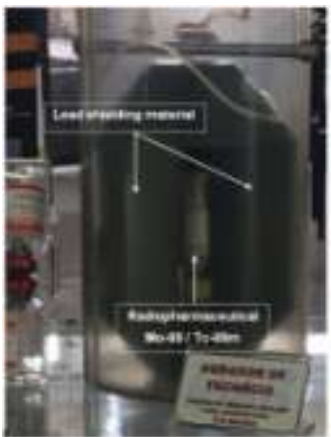

(b)
Figure 1.1: Photo of Ganuk by Nordian(a) and Generator IPEN-TEC (b) with a cut-edge of lead shielding material with radiopharmaceutical Mo$99 / T c-99 m$ in the center of[2, 3].

Generally lead and uranium deplete are used as shielding material but those are environmental harmful. The tungsten is non-toxic and has an important property for radiation shielding that is the atomic density. Using tungsten metal powder with Powder Metallurgy (PM)is possible to obtain a tungsten-copper-nickel (WCuNi) shielding compound and it can be used as an alternative shielding material [1, 4]. The compound has attenuation and shielding properties against gamma $(\mathrm{Y})$ radiation and meets the need for use in stationary or radio-pharmaceutical products transport devices. The production of WCuNi compounds by PM with liquid phase sintering methods and its characterization, experiments to quantify the effective radiation shielding properties is discussed here. Density and porosity of the manufactured PM compounds depends upon pressure, sintering temperature and particle size of each metal alloy [5]. The mass absorption coefficient is dependent of energy and varies according to the density of the respective shielding elements and porosity of the compound material [6].

\section{Materials and production methods}

\subsection{Materials}

Metal powder of tungsten, copper and nickel were used to produce a composite sample of shielding material. The samples were produced with $91 \%$ wt of tungsten, $8 \%$ wt of copper and $1 \%$ wt on nickel.

\subsection{Samples production}

The average particle size in W8Cu1Ni powder composition was $12 \mu \mathrm{m}$. The particle size distribution of each metal powder is important to drive the high average of packaging of the green compacted. The green compacted sample of $\mathrm{W} 8 \mathrm{Cu} 1 \mathrm{Ni}$ was obtained with $11.325 \mathrm{mg}$ of weight metal powder by applying 200 $\mathrm{MPa}$ under isostatic press. After compressed, the final green compact has a roll of porosity with a relative density of $13.24 \mathrm{~g} . \mathrm{cm}^{-3}$. This density depends on distribution of the particles size and applied press energy (Fig. 2.1.a). To obtain a expected densification of the green compacted the samples were sintered in a pressurized furnace. The final sample sintered compound was obtained at temperature of sintering was $1.100{ }^{\circ} \mathrm{C}$ and $2.100 \mathrm{mbar}$ of pressure in reducing atmosphere $\left(\mathrm{H}_{2}\right)$ for 8 hours (Fig. 2.1.b) [5]. After press and sinter samples were prepared for the process of charactization (Fig. 2.1.c).

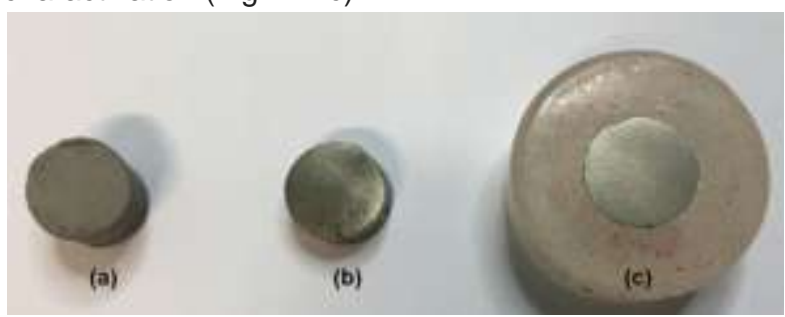

Figure 2.1: (a) Green Compact W8Cu1Ni, (b) Sintered compound sample, (c) Experimental sample.

\section{Samples characterization}

The characterizations were made by six methods, FXR Spectra Granulometry, X Ray Fluorescence, Apparent density [7], Scanning Electron Microscopy (SEM) with Energy Dispersive Spectroscopy (EDS). Experimental attenuation set was used to study behavior of radiation energy picks of Co-60 [6, 8] through the samples and XCOM software database from NIST was used with element simulation to calculate of radiation interaction with compound material [9].

\section{Results}

The particle size of each metal powder used in compound W8Cu1Ni are presented on table 4.1.

Table 4.1 - Results of FRX granulometry for each metal powder before ball milling.

\begin{tabular}{lccc}
\hline \multicolumn{5}{c}{ Main components of compound } \\
\hline $\begin{array}{l}\text { Metallic } \\
\text { Elements }\end{array}$ & $\begin{array}{c}\text { Tungsten } \\
(\mathrm{W})\end{array}$ & $\begin{array}{c}\text { Copper } \\
(\mathrm{Cu})\end{array}$ & $\begin{array}{c}\text { Nickel } \\
(\mathrm{N})\end{array}$ \\
\hline $\begin{array}{l}\text { Particle average } \\
\text { Size }(\mu \mathrm{m})\end{array}$ & $2 \mathrm{~B}, 43$ & 24,56 & 1809 \\
\hline
\end{tabular}

To reduce the average particle size, a ball milling was used for 24 hours. After grinding, the particle size of powder was analyzed by X Ray Fluorescence (table 4.2). The size reduction of metal powder is important for densification on consolidated compound.

Table 4.2 - Results of FRX granulometry and X Ray Fluorescence for the three different metal powder studied on compound.

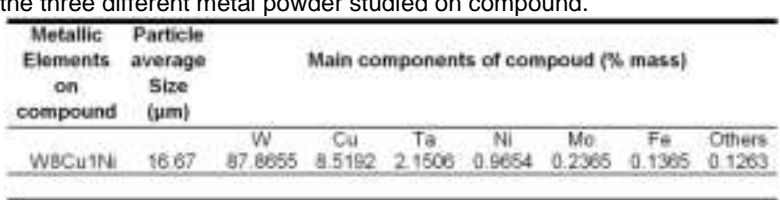

Thereby, the mechanical and metallurgical properties of compound W8Cu1Ni (Fig. 4.1) were determined. The optical microscopy investigations indicate homogeneity 


\section{Encontro Científico de Física Aplicada}

on distribution of tungsten (W) particles and solid phase of cooper-nickel (CuNi) bounding. There were no visible defects as crack, missing parts. After sintering process using liquid phase sintering the sample compound show indicative of ocourrence of porosity and the metallic infiltration consolidating tungsten particles.

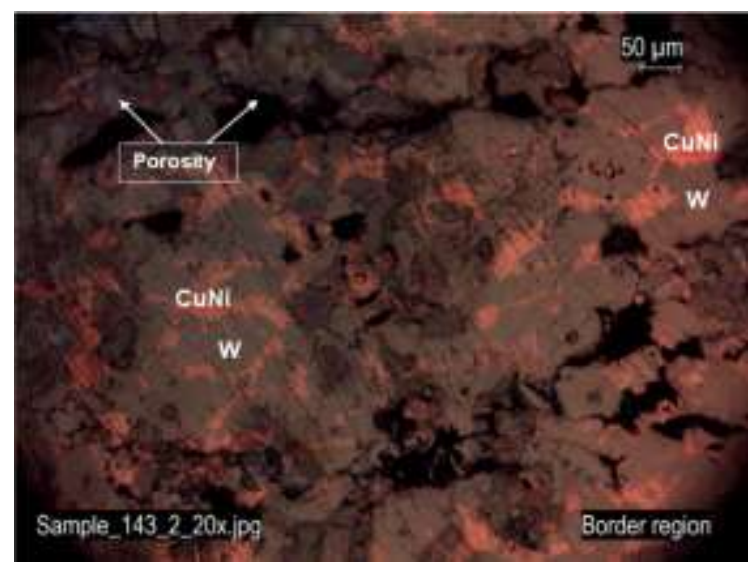

Figure 4.1: Micrographic showing the elements tungsten (W- gray color), cooper-nickel (CuNi- red color) and porosity (black color) over the border of the sample of solid compound W8Cu1Ni.

The results obtained with SEM micrographics reinforce the results of optical microscopy showing the copper nickel alloy as a binder of compound (Fig. 4.2). The surface show CuNi isles on a crow of sample and this can be a migration of liquid CuNi by temperature effect during the sintering process.

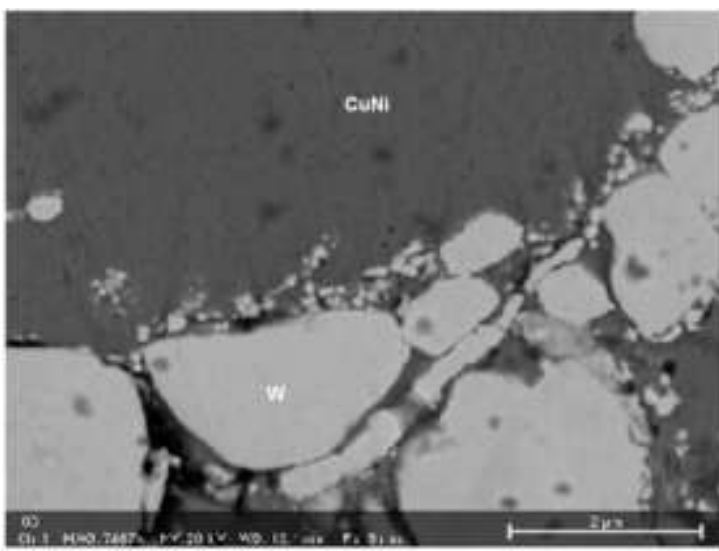

Figure 4.2: Micrographic showing the results obtained during SEM over the border surface of sample W8CuNi, CuNi (dark gray), W (light gray) and porosity (black).

The EDS analysis (Fig. 4.3) in the composite matrix shows predominance of tungsten without the presence of nickel copper alloy.

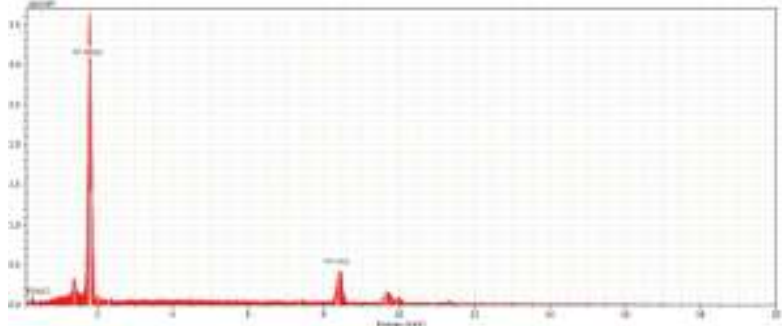

Figure 4.3: Graphic showing the EDS results obtained for $\mathrm{W}$ region on the sample surface showed on figure 4.2 .

The Figure 4.4 shows the EDS result in the nickel copper alloy region of compound and the peaks area presents the 8:1 ratio of metals cooper and nickel presented on liquid phase sintering.

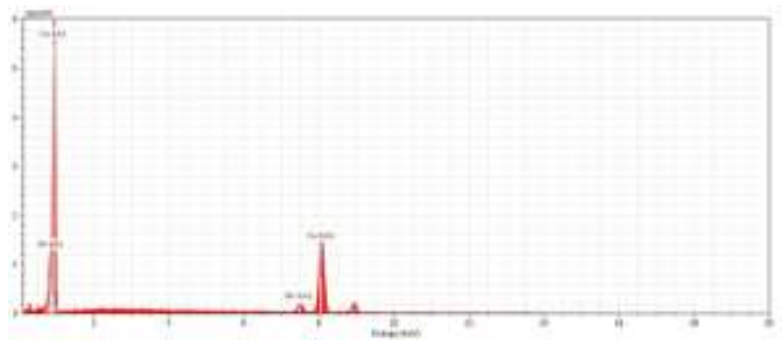

Figure 4.4: Graphic showing the EDS results obtained for $\mathrm{CuNi}$ region on the sample surface showed on figure 4.2.

The graphic on Figure 4.5 shows the results of radiation attenuation experimental trial usingCo-60 as radiation source. The two peaks of photons energy (1173 keV and $1332 \mathrm{keV}$ ) was used to measurements.

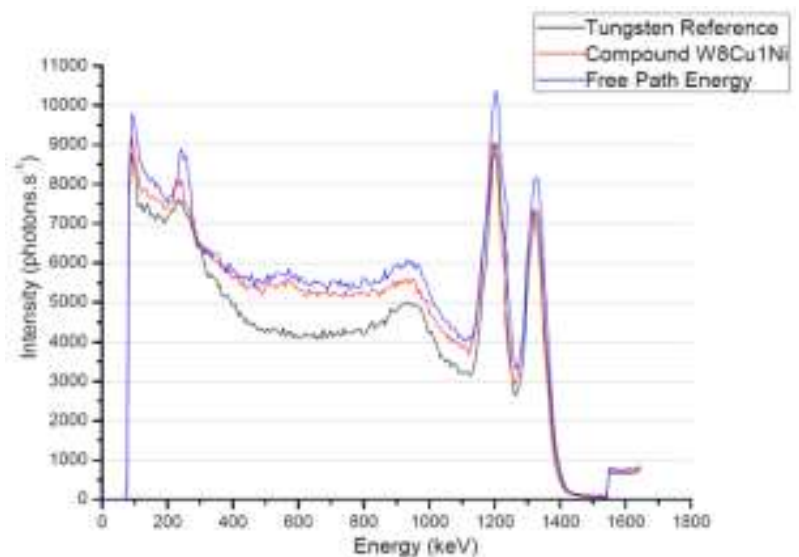

Figure 4.5: Graphic showing Co-60 energy peaks (1.173 and 1.1332 $\mathrm{keV}$ ) comparative attenuation between massive tungsten (W) and solid compound W8Cu1Ni.

The initial calculation of necessary thickness of W8Cu1Ni composite takes the value of individual element in material density and composition. The average of inner porosity $\left(\mu_{\text {air }}\right.$ is possible to evaluate calculating the value of theoretical density and the obtained density for the composite. The difference between thickness of tungsten reference sample and the thickness of sample W8Cu1Ni composite (Table 4.3) could reduce the expected total amount of attenuation obtained for W8Cu1Ni. 


\section{Encontro Científico de Física Aplicada}

Table 4.3 - Measurements of dimensions for tungsten reference sample and dimensions of W8Cu1Ni composite.

\begin{tabular}{ccc}
\hline \multicolumn{3}{c}{ Dimensions (mm) } \\
\hline Samples & Diameter & Height \\
\hline Tungsten (W) & $12,00 \pm 0,05$ & $5,50 \pm 0,05$ \\
\hline W8Cu1Ni & $6,10 \pm 0,05$ & $6,25 \pm 0,05$ \\
\hline
\end{tabular}

The data obtained from experimental test (Table 4.4) follow the Beer Lambert law by equation (1) was used to calculate the attenuation ratio $\mathrm{I}_{(0)} / \mathrm{I}_{(\mathrm{x})}$ by energy and the linear attenuation coefficient of the compound $\mathrm{W} 8 \mathrm{Cu} 1 \mathrm{Ni}$ to define $\mu_{\text {total }}$ of attenuation material.

$$
I_{(x)}=I_{(0)} e^{-\mu \rho t} \quad \text { or } \quad I_{(x)}=I_{(0)} e^{-\mu x}
$$

Where;

$$
\begin{gathered}
\mathrm{I}_{(\mathrm{x})}=\text { intensity after shielding } \\
\mathrm{I}_{(0)}=\text { incident intensity } \\
\mu=\text { mass absorption coefficient }\left(\mathrm{cm}^{2} \cdot \mathrm{g}^{-1}\right) \\
\rho=\text { density of absorber }\left(\mathrm{g} \cdot \mathrm{cm}^{-3}\right) \\
\mathrm{t}=\text { physical thickness of absorber }(\mathrm{cm}) \\
\mathrm{x}=\text { thickness of absorber }\left(\mathrm{g} \cdot \mathrm{cm}^{-2}\right)
\end{gathered}
$$

\begin{tabular}{|c|c|c|}
\hline \multirow{3}{*}{$\begin{array}{l}\text { Target } \\
\text { Elements }\end{array}$} & \multicolumn{2}{|c|}{ Intensity (Photons/s) } \\
\hline & Co- 60 & Co-60 \\
\hline & $(1.173 \mathrm{keV})$ & (1.332 keV) \\
\hline Free Path (Air) & 10368 & 8095 \\
\hline Tungsten (W) & 8714 & 6864 \\
\hline W8Cu1Ni & 9053 & 7261 \\
\hline
\end{tabular}

Table 4.4 - Results of experimental test of radiation attenuation and relative value for studied compound.

\section{Conclusion}

The samples compound produced with metal powder of $91 \%$ wt of tungsten $8 \%$ wt of copper $1 \%$ wt of nickel (W8Cu1Ni) resulted in good mechanical rigidity in terms of solid body, average apparent density and expected radiation attenuation behavior when numerical compared with tungsten $99,9 \%$ of purity.

An oxidation on border of sample surface was observed. This was causing porosity and elevation with cracks. The general results obtained were expected when considered the semi-quantitative analysis of the commercial tungsten powder showed that ratio of purity was lower than $99 \%$ as announced.

New samples will be prepared using press energy of $350 \mathrm{MPa}$ and sintering temperature of $1.350{ }^{\circ} \mathrm{C}$ in a conventional furnace with gas flow. This alternate method is looking for improving density by minimizing porosity and reducing cost of sintering of the composite.

\section{References}

[1] CIONE, F. C., SOUZA, A. C., SENE, F. F., RIZZUTTO, M. A., ROSSI, J. L., A Study of Production of Tungsten Copper Alloy by Powder Metallurgy, Applied to Radioactive Shielding of Transport Equipment for Pharmaceutical Products Euro PM 2015, Reims, France, 2015.

[2] EL-SIBAIE, M., Certificate 0562/B(U) For Package Design Approval - Revision 2 for GANUK Model GA01, German Authority US Department of Transportation Pipeline and Hazardous Materials Safety Administration, Washington, DC, 2010.

[3]https://www.ipen.br/portal por/conteudo/geral/BULA $\% 20$ GERADOR\%20IPEN-

TEC\%20Profissional\%20da\%20saude.pdfAccessed on: August $22^{\text {th }} 2017$.

[4] CHEN, L. C., MA, S. H., Tungsten Heavy Alloys Produced by Liquid Phase Sintering, Jornal of Alloys and Compounds, ELSEVIER, 2017

[5] ABU-OQAIL, A., GHANIN, M., EL_SHEIKH, A., EL_NIKKAILY, A., Effects of Processing Parameters of Tungsten-Copper Composites, Intl Journal Refratory Metals and Hard Materials, ELSEVIER, 2014.

[6] PAIVA, E., Princípios do Cálculo de blindagem em radioterapia, Revista Brasileira do ensino de Física, São Paulo, SP, 2014

[7] ASTM American Society for Testing and Materials. Standard Test Method for: Water Absorption, Bulk Density, Apparent porosity and Apparent Specific Gravity of Fired Whiteware Products. ASTM C 373-88, 1999.

[8] MCALISTER, D. R., Gamma Ray Attenuation Properties of Common Shielding Materials, PG Research Foundation, Lane Lisle, IL, USA, 2013.

[9] Database and Simulation Software XCOM for Total Attenuation https://physics.nist.gov/cgi$\mathrm{bin} /$ Xcom/xcom2, accessed at 07/23/2017, download applicative. 